\title{
The higher education system as the driving force of the country's sustainable development
}

\author{
Maxim Vlasov ${ }^{1,2^{*}}$ \\ ${ }^{1}$ Ural Federal University, 19, Mira str., 620002, Ekaterinburg, Russia \\ ${ }^{2}$ Institute of Economics, Ural Branch of the Russian Academy of Sciences, 29, Moskovskay str., \\ 620014, Ekaterinburg, Russia
}

\begin{abstract}
The article presents results of the research on patterns of the influence such factors as mass character, internationalization and state financing of higher education have on country's innovation development parameters. Conducting correlation analysis allowed for obtaining academic proofs of the fact that in modern conditions above mentioned characteristics of higher education system define innovation development of the country in general. The first part of the article contains analytical review of the literature and identifies characteristics of higher education system the influence of which on country's innovation development the authors consider as significant (mass character, internationalization, state financing). The second part describes the methodology of research and formulated working hypotheses. The third part is a presentation of obtained research results, whereas the fourth part contains conclusions. Theoretical importance of the conducted research is in defining patterns in which such higher education system characteristics as mass character, internationalization and financing model influence certain parameters of innovation development, in particular, the share of hi-tech export in the overall amount of industrial export and the share of research and development costs in GDP.
\end{abstract}

\section{Introduction}

The modern world undergoes intensive processes of structural transformation and institutional change related to forming knowledge --based society and the change of technological pattern. Dynamic changes in modern economy are combined with increasing disproportion in the development of economies of individual countries and the growth of overall uncertainty in the field of searching for reserves and providing foundation for factors of economic growth and scientific and technical progress. In such a case the number of countries actively seeking new solutions in research and technical policy increases significantly. As we know there are four main branches of science that serve as the source of innovation: academic, higher education, sectoral and technological. During the recent years, the statement that the development of higher education branch of science should play the defining role in the process of country innovation development is quite popular. The question arises concerning which criteria higher education system should meet to become innovation

\footnotetext{
*Corresponding author: mvlassov@mail.ru
} 
development driver. The need for finding an answer to this question determines the relevance of the research.

The aim of the conducted research is to define the characteristics of higher education system, which facilitate achieving the indicators of innovation development of the country.

Researchers believe that universities define the vector of innovation development and become the basic element of national innovation systems, which provides knowledge generation. Universities play the key role in forming human capital in the field of educational characteristics and this is of great importance for stimulating economic growth and innovation development. Having studied interrelation between human capital and innovation potential and its influence on economic growth S. Muhamad, N. F. Che Sulaiman and J. Saputra concluded that the human capital of the country depends on characteristics of higher education system and the amount of state expenditures on education [12]. T.P. Cheremisina believes that development of higher education and science, the main institutions providing human capital formation, is a prerequisite for stimulating innovation activities [5]. According to G.A. Reznik and M.A. Kurdova modern universities should become the foundation for developing research and innovation [17]. M.A. Afonosova points out that in the context of digital transformation of economy only higher education can become the driver of innovation development and stability of economic growth [2]. C. Birch, J. Lichy, G. Mulholland, M. Kachour believe that forming and encouraging flexible thinking, creativity, supporting the testing of new ideas and ways of implementing them, adapting to innovations are extremely important future factors of innovation development and the foundation for them can be formed only at higher education institutions [4].

Traditionally higher education system of the country is characterized according to the following parameters: level of liberalization, scope (mass/elite), financing system, internationalization, approaches to forming educational programs, etc. Further we will investigate those characteristics which researchers believe to have the most influence on innovation development parameters.

\subsection{Mass/elite nature of higher education}

One of the features of large -scale transformation of higher education system during the last facades was the transition from elite education to mass education.

Having analyzed the results of conducted empirical macroeconomic research B. Kamar, D. Bakardzhieva, M. Goaied concluded that the policy of the government encouraging loans and increased expenditures on educations at higher education institutions alongside with creation of new budget places for students leads to the growth of country economy [10].

J. Whetten, M. Fontenla, K. Villa believe that decrease of budget limitations, increase of grants for higher education, that is broadening the scope of entrance opportunities at higher education institutions lead to positive economic effect in the development of country economy [21].

As a result of research into entrepreneurial education A. Gibb suggested that alongside with number of students, accessibility, and mass nature of education another important factor is the formation of entrepreneurial competencies among the students [8]. Therefore, we can assume that innovation development parameters are influenced by characteristics of business education in the country and by the number of students taking business, administration and law programs.

For developing countries especially those with pronounced gender inequality problem one of the aspects of mass education is its accessibility for women and inclusion of female lecturers into the process of academic and research activities.

W. Lai, L. Smith see female lecturers as innovation development drivers as they feel more positive about the need for constant upgrading qualification and the use of digital 
technologies in education [11].

Now there is a universal trend for increasing not only the number of women studying at higher education institutions but also the number of female lecturers at universities. The influence of this fact on innovation development is studied in the research by A. Weymann [20].

On the one hand, mass education is the answer for structural and technological modernization of the economy and humanization and informatization of the society. Some researchers believe that the growth of the number of higher education students was the key factor in international higher education system in XXI [3].

On the other hand, mass education is associated with lower quality: average quality of first year students is lower, the amount of state financing for one student decreases, which can lead to decline in research, academic and innovation activities.

There are different opinions on increasingly mass character of higher education (frequently opposing ones) which increase the need for analyzing the patterns of mass education influence on different aspects of innovation development.

\subsection{Higher education financing}

During the recent years, many countries were engaged in the reform of higher education. Majority of these reforms was related to the mechanism of resource distribution (mainly in forming dependence between state financing share and university activities results) as well as competitive approach in overall resource distribution [1].

S. Nistor, V.-I. Mera, M. I. Pop Silaghi inform that countries with considerable state expenses on higher education are characterized with higher level of innovation activities as compared to the countries with low level of state expenses on higher education [14].

According to Neck et al successful policy aimed at facilitating economic growth in a longterm perspective should be based on improving human capital and technical progress. Based on collected empirical data researchers prove that in case of increased higher education financing the amount of innovation goods manufacturing will grow on a permanent basis. They conclude that investment into human capital is the key to sustainable growth and prosperity [13].

Analyzing state expenses on scientific research and institutional mechanism of coordinating scientific research between the government and the private sector E. E. Patalinghug proves that stimulation of innovation development requires increased state financing of academic and technical education at the level of higher education institutions [16].

On the other hand, research conducted by certain scientists point out that increased state financing of university expenses does not always lead to stimulation of innovation development. Research conducted by Korean scientists T. E. Webster, J.-B. Son shows that despite the growth of state financing of higher education institution university lecturers are not willing to use new technologies in their professional activities which limits the formation of students' innovation potential [19]. Therefore, an increasing number of researchers agree that the structure of university innovation development financing is no less important than the amount of financing. Therefore, more and more researchers agree with the thesis that the structure of university innovation development financing trends has no less importance than the amount of financing. For example, according to research by C. Franco and R. Leoncini innovation development is under strong and stable influence of state expenditures on patents as well as investments into research and development activities [7].

Authors conducted an analytic review of research articles on the topic of the influence of amount of state financing of higher education on the parameters of innovation development of the country. The results of the analysis lead to the conclusion that despite the considerable 
amount of research many questions remain unanswered. In particular, we still do not know the degree of influence of the prevailing state education in the country has on innovation development or how innovation development parameters are related to the size of the salary received by university employees.

\subsection{Higher education internationalization}

According to the definition provided by Organization for Economic Co-operation and Development (OECD) education internationalization is a process during which aims, functions and organization of education services obtain and international dimension. Internationalization in the higher education traditionally includes two aspects: "internal" internationalization and "external" internationalization, or education abroad, inter - country education trans-border education [15].

Results of the research conducted by L. Criseli et al point out the importance of international student and researchers mobility programs for most of innovation development indicators [6].

According to T. Tang et al student mobility is the basis of university innovation development and therefore of the regions in which these universities are situated [18].

The article by E. Goulicheva et al the problem of forming innovation education environment at he universities is analyzed alongside with the problem of providing long-term competitiveness of education services both at the national and global markets. They suggest a model for managing innovation education environment with particular attention on international student mobility as the basis for export/import of new knowledge [9].

Modern universities wish to combine national peculiarities of educational system with new trends induced by globalization to provide acceptable level of competitiveness at the educational services market. However, internationalization has another effect: many talented students and lecturers go to other countries and stay there forever. In other words, the quality and quantity of human capital necessary for innovation development of the country, dwindles.

Therefore, conducted analytical review of academic literature on the topic gives grounds to believe that orientation towards mass higher education, level of its' state financing and internalization degree are of considerable importance for obtaining target innovation development performance in the country. At the same time researches have not reached unanimity concerning the direction of this influence. Part of the researchers believes that mass nature of higher education is an absolute benefit for innovation development, others see the link between mass education and decreasing quality and doubt the opportunity of combining high level of innovation development with increased number of university students. Many researchers point out that increased state financing of higher education without quality analysis of the results of this financing does not have any significant influence on innovation activity growth. And finally, internationalization process can be a benefit from the point of view of knowledge and innovation diffusion but also can act as a factor of "brain drain".

\section{Research methodology}

Based on above-presented literature sources analysis the authors formulated three hypotheses.

1. High number of university students has positive influence on innovation development of the country.

In this case the number of university students reflects the degree of mass character of higher education. At the same time the authors agree that besides mass character of higher 
education the spread of students between educational programs also plays an important role in innovation development of the country. For example relatively high proportion of students taking such programs as Science, Technology, Engineering and Mathematics can possibly have positive influence on innovation generation, whereas the introduction of innovation will be facilitated by a great number of students at such programs as в Business, Administration and Law.

2. Increase of state financing for higher educational institutions leads to innovation growth.

In this case authors see the indicator characterizing government expenditures on tertiary education as \% of GDP as the most informative one. Besides that, the share of expenditures on higher education in the overall amount of state financing of education is also important. The structure and efficacy of financing are frequently more important for achieving objectives than the amount of financing therefore one of the indicators characterizing higher education system is the share of lecturers' salary in the overall amount of state expenditures on higher education.

3. Internationalization of higher education institutions stimulates innovation activities.

In order to test this hypothesis, the authors chose several indicators reflecting the process of university internationalization: Gross outbound enrolment ratio, Inbound mobility rate, Outbound mobility ratio, Net flow ratio of internationally mobile students (inbound outbound).

The choice of these indicators depended on two conditions. First of all, the chosen indicators have been collected and accumulated by the World Bank for many years and contain data from majority of countries. Second, authors believe these indicators fully reflect the higher education system processes under research.

The information was taken from statistic database of World Bank on higher education World development indicators, which is renewed on an annual basis. Research was conducted on the data presented for 2019 covering 153 countries for the period from 2014 till 2018 (see https://databank.worldbank.org/source/education-statistics-\%5e-all-indicators).

In order to define characteristics of higher education system facilitating innovation development of the country and check formulated hypotheses correlation analysis was conducted.

With the help of correlation analysis, we can pretty accurately determine the factors having the most pronounced influence on performance indicator on the basis of measuring the correlation between them. Data interpretation was conducted using Chaddock scale allowing to transform quantitative data into a qualitative characteristic. Correlation coefficient over 0,75 means that factor have direct strong connection. In correlation coefficient is 0,7 and lower the meaning is quite the opposite. The lower the coefficient is the lesser the interrelation and mutual influence between the factors. Authors used the following variables to characterize innovation development results: High-technology exports $(\%$ of manufactured exports) и Research and development expenditure (\% of GDP).

\section{Results}

During the analysis of empirical data and construction of correlation dependencies the authors formulated the following results:

The growth of higher education students numbers in many countries has mostly positive influence on innovation development of these countries (Table 1). 
Table 1. The influence of mass higher education on innovation development of the countries included into the pool for research.

\begin{tabular}{|l|c|c|}
\hline \multirow{2}{*}{ Indicator } & \multicolumn{2}{|c|}{ Variable } \\
\cline { 2 - 3 } & $\begin{array}{c}\text { High-technology exports. \% } \\
\text { of manufactured exports }\end{array}$ & $\begin{array}{c}\text { Research and development } \\
\text { expenditure. \% of GDP }\end{array}$ \\
\hline $\begin{array}{l}\text { Gross enrollment ratio. } \\
\text { tertiary. both sexes. \% }\end{array}$ & 0.81 & 0.79 \\
\hline $\begin{array}{l}\text { Gross enrollment ratio. } \\
\text { tertiary. female. }\end{array}$ & 0.81 & 0.76 \\
\hline $\begin{array}{l}\text { Percentage of graduates } \\
\text { from Science. Technology. }\end{array}$ & & \\
$\begin{array}{l}\text { Engineering and } \\
\text { Mathematics programs in } \\
\text { tertiary education. both } \\
\text { sexes.\% }\end{array}$ & 0.92 & 0.48 \\
\hline $\begin{array}{l}\text { Percentage of graduates } \\
\text { from tertiary education } \\
\text { graduating from Business. } \\
\text { Administration and Law } \\
\text { programs. both sexes. \% }\end{array}$ & & \\
\hline
\end{tabular}

Chosen parameters of innovation development of the country (the share of hi-tech export in overall export amount and the share of R\&D expenditures in GDP) and the scope of population and women enrolled into higher education form strong correlation.

There is a strong correlation between variables characterizing percentage of students enrolled in Science, Technology, Engineering and Mathematics programs and the share of hitech products export in overall export amount. It is possible that the number of students taking Business, Administration and Law programs also has positive influence on hi-tech export share as the correlation is in the scope of $0,5-0,7$, meaning average positive correlation. Other indicators of the correlation between variables were insignificant.

Research results demonstrate that the amount of state financing of higher education is one of the significant factors facilitating innovation development of the country (Table 2).

Table 2. The influence of state financing of higher education on innovation development of the countries included into the research pool.

\begin{tabular}{|l|c|c|}
\hline \multirow{2}{*}{ Indicator } & \multicolumn{2}{|c|}{ Variable } \\
\cline { 2 - 3 } & $\begin{array}{l}\text { High-technology exports (\% } \\
\text { of manufactured exports) }\end{array}$ & $\begin{array}{c}\text { Research and development } \\
\text { expenditure (\% of GDP }\end{array}$ \\
\hline $\begin{array}{l}\text { Percentage of enrollment in } \\
\text { tertiary education in private } \\
\text { institutions.. \% }\end{array}$ & 0.35 & -0.24 \\
\hline $\begin{array}{l}\text { Expenditure on tertiary as \% of } \\
\text { government expenditure on } \\
\text { education. \% }\end{array}$ & 0.75 & 0.75 \\
\hline $\begin{array}{l}\text { Government expenditure on } \\
\text { tertiary education as \% of } \\
\text { GDP. \% }\end{array}$ & 0.57 & 0.78 \\
\hline $\begin{array}{l}\text { Teaching staff compensation } \\
\text { as a percentage of total } \\
\text { expenditure in tertiary public } \\
\text { institutions. \% }\end{array}$ & -0.57 & 0.54 \\
\hline
\end{tabular}

There is a strong correlation between the share of hi-tech export in the overall amount of export, share of expenditures on research and development in the overall GDP and indicators and share of expenditures on higher education system in the overall amount of education 
financing of the state. There is an average correlation between the share of state expenditures on higher education in GNP and the parameters of hi-tech products export. Percentage of students at private universities does not influence innovation development of the country. Perhaps this result from the fact that in the countries with a large number of private universities the government offers financing for higher education via a broad network of funds providing grants directly to students. Authors found an unexpected average negative correlation between variables characterizing the share of lecturers' salary in an overall amount of expenditures on higher education.

Higher education internationalization definitely has a positive effect on innovation development of the country (Table. 3).

Table 3. The influence of higher education internationalization on innovation development of the countries included into the research pool.

\begin{tabular}{|l|c|c|}
\hline \multirow{2}{*}{ Indicator } & \multicolumn{2}{|c|}{ Variable } \\
\cline { 2 - 3 } & $\begin{array}{c}\text { High-technology exports (\% } \\
\text { of manufactured exports) }\end{array}$ & $\begin{array}{c}\text { Research and development } \\
\text { expenditure (\% of GDP }\end{array}$ \\
\hline $\begin{array}{l}\text { Gross outbound enrollment } \\
\text { ratio. all regions. both sexes. \% }\end{array}$ & 0.91 & 0.91 \\
\hline $\begin{array}{l}\text { Inbound mobility rate. both } \\
\text { sexes. \%) }\end{array}$ & 0.80 & 0.86 \\
\hline $\begin{array}{l}\text { Outbound mobility ratio. all } \\
\text { regions. both sexes. \% }\end{array}$ & 0.77 & 0.79 \\
\hline $\begin{array}{l}\text { Net flow ratio of } \\
\text { internationally mobile } \\
\text { students (inbound -outbound). } \\
\text { both sexes. \% } \%\end{array}$ & 0.89 \\
\hline
\end{tabular}

All analyzed variables describing the degree of higher education internationalization have direct strong and very strong correlation with the chosen parameters of innovation development of the economics (the share of hi-tech export in overall export amount and the share of expenditures on research and development in GDP). Authors' hypothesis on negative effect of high percentage of students studying abroad on innovation development of the country was not proven.

Therefore, authors conclude that all suggested hypotheses were confirmed and the aim of the research was achieved.

\section{Conclusions}

Conducted research allowed for defining correlations between variables characterizing mass nature, internationalization, system of state financing of higher education and variables characterizing innovation development of the countries included into the research pool. It was stated that innovation development of the country is positively influenced not only by mass nature of higher education (high level of population involvement into higher education) but also by the increased number of students taking such programs as Science, Technology, Engineering and Mathematics in the overall amount of university students and (to a lesser degree) by the increased number of students enrolled in Business, Administration and Law programs.

The share of state financing of higher education measured as the share of GNP has a role in innovation development but it is less significant than the role of the structure of education financing: the larger the share of university financing in the overall education financing is, the higher the indicators of innovation development of the country are. At the same time 
decrease of the share of university lecturers' salary in overall expenditures on higher education has a positive influence on innovation development.

It has also been found that all forms of higher education internationalization, including the share of students taking courses at foreign universities have positive influence on innovation development of the country.

Therefore, the strategy of the university dedicated to making an input to innovation development of the country should include:

- the search of ways for increasing involvement of majority of population into higher education;

- broader scope of offered programs in Science, Technology, Engineering and Mathematics и Business, Administration and Law;

- stimulation of research and academic activities of lecturers and increase of research staff, as well as attraction of scientists from elsewhere;

- development of student mobility programs.

Based on obtained results authors believe that educational policy of the state concerning higher education should include the following components:

- increasing the share of higher education financing in overall amount of expenditures on education;

- stimulating international mobility of students and lecturers;

- forming demand and supply in programs related to Science, Technology, Engineering;

- providing benefits and extra opportunities for obtaining education for women.

Theoretical importance of the conducted research is in providing the basis for those higher education system characteristics which facilitate activation of certain innovation processes. Obtained results can serve as a starting ground for researchers in organizing and conducting further research related to defining resources for innovation development on a macroeconomic level.

Practical importance of this research is in opportunity for using obtained results in developing strategic plans and development programs at the level of both individual universities and regions and countries.

\section{Acknowledgement}

The article has been prepared in accordance with the state assignment for the Institute of Economics of Ural Branch of RAS for 2021.

\section{References}

1. I.V. Abankina, T.V. Abankina, E.A. Nikolaenko, L.M. Filatova, Education economy 1(74), 53-73 (2013)

2. M.A. Afonasova, Journal of Entrepreneurship Education 21(2) (2018)

3. P.G. Altbach, L. Reisberg, L.E. Rumbley, Trends in Global Higher Education: Tracking an Academic Revolution (Sense, Rotterdam, Netherlands, 2010)

4. C. Birch, J. Lichy, G. Mulholland, M. Kachour, Journal of Management Development 36(6), 743-760 (2017) doi10.1108/jmd-03-2016-0036

5. T.P. Cheremisina, Journal of Novosibirsk State University. Series: Social and economic sciences 14(3), 64-72 (2014)

6. M.L. Cricelli, M. Greco, L.P. Grimaldi, L. Dueñas, Journal of Intellectual Capital 19(1), 71-95 (2018) 
7. C. Franco, R. Leoncini, Economics of Innovation and New Technology 22(2), 199217(2013)

8. A. Gibb, International Journal of Entrepreneurial Behaviour and Research 17(2), 146165 (2011) doi:10.1108/13552551111114914

9. E. Gulicheva, E. Lisin, M. Osipova, A. Khabdullin, Journal of International Studies 10(2), 129-137 (2017)

10. B. Kamar, D. Bakardzhieva, M. Goaied, Applied Economics 51(40), 4337-4367 (2019) doi:10.1080/00036846.2019.1591596

11. K.W. Lai, L. Smith, British Journal of Educational Technology 49(3), $492-504$ (2018) doi:10.1111/bjet.12544

12. S. Muhamad, N.F. Che Sulaiman, J. Saputra, Jurnal Ekonomi Malaysia 52(1), 281-295 (2018) doi: 10.17576/jem-2018-5201-21

13. R. Neck, K. Weyerstrass, D. Blueschke, B. Majcen, A. Srakar, M. Verbič, International Advances in Economic Research 24(2), 109-121 (2018) doi:10.1007/s11294-018-96788.

14. S. Nistor, V.-I. Mera, M.I. Pop Silaghi, Applied Economics 50(34-35), 3840-3854 (2018) doi:10.1080/00036846.2018.1436149

15. Internationalisation and trade in higher education: opportunities and challenges (OECD. Centre for Educational Research and Innovation, Paris, 2004)

16. E.E. Patalinghug, International Journal of Technology Management 22(5/6), 599-616 (2001)

17. G.A. Reznik, M.A. Kurdova Education integration 21(3), 441-458 (2017)

18. T. Tang, Z. Wu, K. Karhu, M. Hämäläinen, Y. Ji, Journal of Emerging Technologies in Web Intelligence 4(1), 106-115 (2012)

19. T.E. Webster, Computers and Education 80, 84-94 (2015)

20. A. Weymann, Theory and History of Education 19, 6-34 (2018) doi: 10.24908/eoe-eserse.v19i0.11930

21. J. Whetten, M. Fontenla, K. Villa, Oxford Development Studies 47(2), 222-237 (2019) doi:10.1080/13600818.2018.1539472 